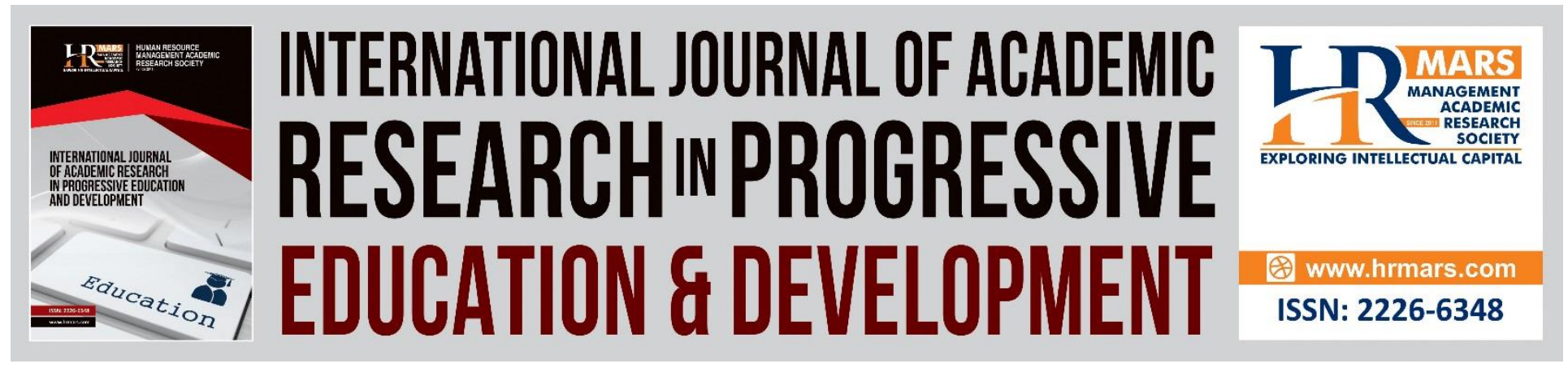

\title{
Exploring Primary School Teachers' Challenges in Incorporating Higher Order Thinking Skills (HOTS) in English Classroom
}

Hana Melinda Musa, Hamidah Yamat

To Link this Article: http://dx.doi.org/10.6007/IJARPED/v10-i2/9970

DOI:10.6007/IJARPED/v10-i2/9970

Received: 04 April 2021, Revised: 08 May 2021, Accepted: 24 May 2021

Published Online: 17 June 2021

In-Text Citation: (Musa \& Yamat, 2021)

To Cite this Article: Musa, H. M., \& Yamat, H. (2021). Exploring Primary School Teachers' Challenges in Incorporating Higher Order Thinking Skills (HOTS) in English Classroom. International Journal of Academic Research in Progressive Education and Development, 10(2), 665-674.

Copyright: (C) 2021 The Author(s)

Published by Human Resource Management Academic Research Society (www.hrmars.com)

This article is published under the Creative Commons Attribution (CC BY 4.0) license. Anyone may reproduce, distribute, translate and create derivative works of this article (for both commercial and non-commercial purposes), subject to full attribution to the original publication and authors. The full terms of this license may be seen at: $\underline{\text { http://creativecommons.org/licences/by/4.0/legalcode }}$

Vol. 10(2) 2021, Pg. 665 - 674

http://hrmars.com/index.php/pages/detail/IJARPED

JOURNAL HOMEPAGE

Full Terms \& Conditions of access and use can be found at http://hrmars.com/index.php/pages/detail/publication-ethics 


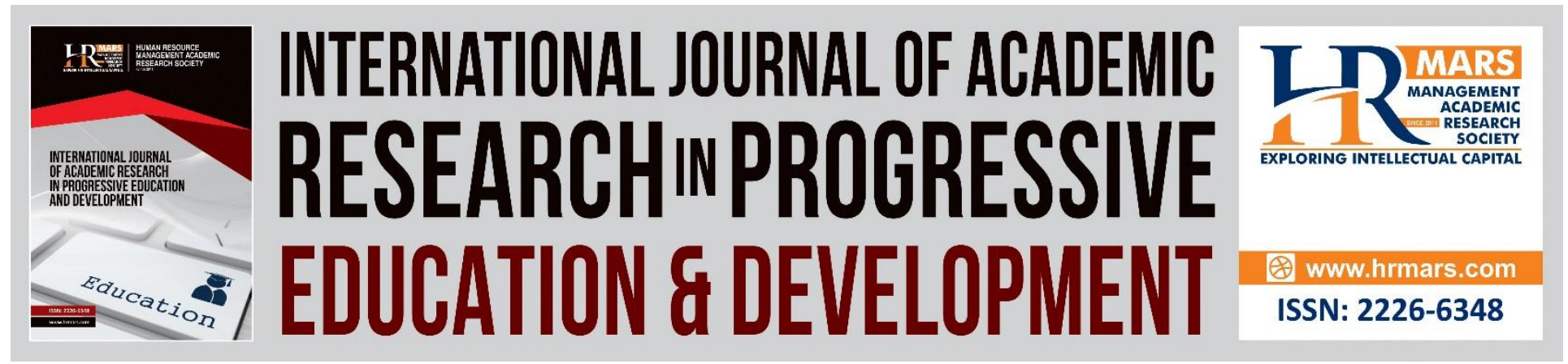

\title{
Exploring Primary School Teachers' Challenges in Incorporating Higher Order Thinking Skills (HOTS) in English Classroom
}

\author{
Hana Melinda Musa \\ SK Cardinal Vaughan, 96850 Song, Sarawak, Malaysia \\ Email: hanamelinda994@gmail.com
}

Hamidah Yamat

Faculty of Education, National University of Malaysia (UKM),43600 Bangi, Selangor, Malaysia.

Email: hamidah_yamat@ukm.edu.my

\begin{abstract}
Primary School Malaysia teachers struggle to incorporate Higher Order Thinking Skills (HOTS) in the English classroom. Hence, this descriptive research was conducted among 30 English teachers in Song, Sarawak. It aims to identify the teachers' challenges while incorporating the HOTS in teaching English classrooms. The data collection method used in this study was survey questionnaires. The data were analyzed using a 4- liked scale. The finding revealed that teachers still have faced some challenges in incorporating HOTS in their classrooms. Through the analysis from the survey questionaries, three subthemes were identified. The three subthemes are Teacher's Knowledge, Teacher's preparation, and Pupil's Aspect.

Keywords: Higher Order Thinking Skills (HOTS), Incorporation, Challenges, Primary School Teacher, English Classroom
\end{abstract}

\section{Introduction}

In general, HOTS teaching and learning tend to be associated with science and mathematics rather than subjects such as language in the arts, especially at the primary school level. Perhaps that is why there was limited incorporation of HOTS into the language classroom. Higher-order thinking skills (HOTS) have always become a hot issue in education (Latief, Pabbajah, \& Karim, 2016). Since decades ago, the significance of those thinking skills has been recognized. It can also be concluded that HOTS should not have been an issue for educators of all generations to integrate it into their classroom.

When teachers are forced to adjust their teaching methods in the classrooms, they are prepared to fit into the exam-oriented framework. Some teachers also face difficulties, according to studies, to ensure that HOTS is included in their lessons. Rajendran (2008), in his studies, noted 
that the majority of teachers do not show adequate readiness to teach thought skills. Tang and Tan (2015) have reported that the method of professional training does not promote the promotion of curious minds and analytical skills because teacher trainees mostly use facts and numbers to memorize. In the same way, several studies have shown that too much emphasis is put on rote leaves in classroom learning and educational institutions.

The above problems illustrate an implementation difference that can be found between the written policies and their execution. According to the UNESCO study, teachers in Malaysia do not have adequate understanding and awareness of classroom activities that conform to the curriculum's theory and goals. Such problems can pose a big question as to whether such a phenomenon can occur. In order to tackle the issues, challenges that occur during the incorporation of Higher Order Thinking Skills (HOTS) must be identified.

\section{Literature Review}

The learning skills of the 21st century concentrate more on the growth of critical and creative thinking skills. Critical thinking ability helps a person solve problems, while creative thinking ability helps a person to create new and authentic ideas and to be able to think outside the box. The 21st-century world is expected to have a very high demand for innovative thinkers and critical problem solvers.

The latest taxonomy used is Anderson et al. (2001) updated edition of Bloom's taxonomy (2001). The taxonomy acts as instructions to map the cognitive domain of students. There are six stages of cognitive processes in the multi-tiered model of classifying thinking processes. The stage is according to the level of cognitive complexity. The lowest three levels consist of remembering, understanding, and applying, known as Lower Order Thinking Skills (LOTS). In the meantime, the three highest levels, also known as Higher Order Thinking Skills (HOTS), consist of analyzing, evaluating, and creating.

In the incorporation of HOTS in the Malaysian education system, the Ministry has outlined seven components. Curriculum, pedagogy, and assessment are the three principal components. Meanwhile, the four other components are co-curricular, community and private support, capacity building, and resources, which are considered the supporting elements. In terms of curriculum, the Ministry has developed a revised curriculum known as KSSR (for elementary school) and KSSM (for secondary school), which encourages and improves the development of HOTS in the learning process. The new KSSR offers an increased focus on higher-order thinking and is a clear step in the right direction of curriculum reform.

\section{Challenges in Incorporation of High Order Thinking Skills (HOTS)}

Although HOTS is significant, many educators are ill-equipped in the classroom to incorporate HOTS. According to Yeung (2015), though teachers exhibit a while awareness of what HOTS entails, many are unable to turn their Higher Order Thinking Skills (HOTS) awareness into practices. Consequently, insufficient teacher preparation may lead to the failure of incorporating HOTS into the classroom.

In improving the higher-order thinking skills of pupils, teachers also play a crucial role. It takes a lot of time and engagement from educators to develop resources that inspire HOTS through appropriate activities and teaching methods. The teaching and learning activities that take place 
in the classroom may not be consistent with HOTS fostering, though, due to any actual or assumed limitations. According to Preece and Adila (2014) in Aziz et al. (2017), the teaching and learning practices in Malaysian classrooms are presumed to be teacher-centered, where connections between student and teacher are minimal, and there is no promotion of higherorder thinking skills (HOTS).

Fern and Umi Kalsum (2015) argue that it is relatively new to incorporate Higher Order Thinking Skills (HOTS) in Malaysian classrooms and that both teachers and students need time to adapt. Ganapathy et al. (2017), teachers must be introduced to good teaching frameworks that emphasize the application of Higher Order Thinking Skills (HOTS), arguing that teachers face difficulties incorporating HOTS into their teaching.

Such problems can raise an important question as to why such phenomena can happen. There are known to be several variables affecting the successful learning method of teaching; research conducted by Seman et al. (2017) shown that educators are one of the key influences affecting HOTS teaching success or loss. The position of teachers is, therefore, obviously important. Any action that teachers take will decide whether or not the teaching is effective. In reality, the behaviour of teachers cannot be separated from their opinions on how they perceive and see everything.

\section{Research Objectives}

1. To identify the teachers' challenges while incorporating the HOTS in teaching English classrooms

\section{Methodology}

Creswell and Guetterman (2019) claimed that researchers are encouraged to develop professional understanding and agreement with research participants to ensure clear study directions and to ignore any ethical concerns that might occur within the study. In this research, the researcher does not monitor the participants because of the Movement Control Order (MCO) by the government. Nevertheless, the participants were given an introduction and the purpose of the study before collecting the data. The participants are English teachers, and they at least had one year of teaching experience. There is a total of 30 English teachers involved.

Creswell \& Guetterman (2019) stated that the selection of data collection instruments depending primarily on the nature, purposes, and objectives of the research. Therefore, the data collection method for this study is survey questionnaires. Statistical analysis will be carried out on the survey questionnaire. As stated by Asún, Rdz- Navarro, and Alvarado (2016), descriptive statistics such as mean and standard deviation are suitable to be employed on series of combined questions that measure a particular trait in a Likert scale. Hence, the findings of the survey questionnaire will also be analyzed through SPSS Version 23 for descriptive statistics involving mean, standard deviation, and percentages.

The data in this analysis were extracted from the sample questionnaire. The questionnaire is made up of 3 crucial subthemes. The first section is the basic details of the participant, and the second is the difficulties encountered by the teacher in incorporating HigherOrder Thought Skills (HOTS), which divided into three sections, including the knowledge of the teacher, the preparation of the teacher, and the factor of the pupils. The questionnaire consists 
of 15 close-ended items, gauging the teaching challenges during the incorporation of the High Order Thinking Skills (HOTS). Each of the items is rated on a Likert scale of 1 to 4 to indicate the degree to which the participants agree or disagree with any of the given statements based on their judgments and experiences.

\section{Findings}

The findings are divided into three subsections following the central themes of this study, namely the challenges that are faced by the teacher during the incorporation of Higher Order Thinking Skills (HOTS). There are 15 items included in the survey questionnaires, and the Likert Scale used in the section are 4 (Strongly agree), 3 (Agree), 2 Disagree) and 1 ( Strongly disagree).The interpreted value for this section is 3.26 - 4.00 (Strongly agree), $2.51-3.25$ (Agree), $1.76-2.50$ (Disagree) and $1.00-1.75$ (Strongly disagree).

\section{Teacher's Knowledge}

The findings of teachers' challenges on the use of Higher Order Thinking Skills (HOTS) on the teachers' knowledge aspect have the mean that is over 2.0. Items 3 has the highest mean of 3.033 which $92 \%$ of teachers agreed that they have experience in incorporate HOTS in their teaching. However, item 2 has the lowest mean of 2.17 when $76.7 \%$ of teachers admitted that they had not attended more than 5 courses on HOTS. This explained why item 6 has the second-lowest mean of 2.47; from the statements, teachers have not reached the high level of thinking to deal with the pupil's questions when incorporating HOTS. A total of $53.3 \%$ of teachers disagree that they have reached a high level of thinking to deal with the pupils' questions when incorporating HOTS.

\begin{tabular}{|c|c|c|}
\hline & Mean & Interpretation \\
\hline 1. I have sufficient training on HOTS. & 2.47 & A \\
\hline $\begin{array}{l}\text { 2. I have attended more than } 5 \\
\text { courses on HOTS }\end{array}$ & 2.17 & $\mathrm{D}$ \\
\hline $\begin{array}{l}\text { 3. I have experience incorporate } \\
\text { HOTS in my teaching. }\end{array}$ & 3.03 & A \\
\hline $\begin{array}{l}\text { 4. I am incorporating HOTS because } \\
\text { I know of it }\end{array}$ & 2.43 & $\mathrm{D}$ \\
\hline $\begin{array}{l}\text { 5. I am confident what I give to my } \\
\text { students were HOTS. }\end{array}$ & 2.47 & $A$ \\
\hline $\begin{array}{l}\text { 6. I have reached a high level of thinking } \\
\text { to deal with the pupils' questions when } \\
\text { incorporating HOTS. }\end{array}$ & 2.47 & $\mathrm{D}$ \\
\hline Average Mean & 2.50 & $A$ \\
\hline
\end{tabular}


Vol. 10, No. 2, 2021, E-ISSN: $2226-6348$ @ 2021 HRMARS

\section{Teacher's Preparation}

The findings of teachers' challenges on the use of Higher Order Thinking Skills (HOTS) on the teachers' preparation aspect have a mean of over 2.8. Items 1 has the highest mean of 3.167 which all the teachers agreed that extra efforts are spent to apply HOTS in teaching. This explained why item 2 comes with the second highest in the survey, where $93.4 \%$ of the teachers agree that they take extra time to schedule lessons more precisely and efficiently. This is further supported by the statement in item 3 , in which $82.7 \%$ of teachers agree that incorporating HOTS in teaching requires a sophisticated array of activities.

\begin{tabular}{|l|l|l|}
\hline & Mean & $\begin{array}{l}\text { Interpretatio } \\
\text { n }\end{array}$ \\
\hline $\begin{array}{l}\text { 1.Extra efforts are spent to apply } \\
\text { HOTS in teaching. }\end{array}$ & 3.17 & A \\
\hline $\begin{array}{l}\text { 2. I am taking extra time to schedule } \\
\text { lessons more precisely and efficiently. }\end{array}$ & 3.10 & A \\
\hline $\begin{array}{l}\text { 3. Incorporating HOTS in the teaching } \\
\text { requires a sophisticated } \\
\text { array of activities. }\end{array}$ & 3.00 & A \\
\hline $\begin{array}{l}\text { 4. I find it hard to create a conducive } \\
\text { classroom environment when } \\
\text { incorporating HOTS into my pupils. }\end{array}$ & 2.83 & A \\
\hline $\begin{array}{l}\text { 5. I find it difficult to change a plan that } \\
\text { would include all learning areas within the } \\
\text { timeline set out in the Standard Document } \\
\text { of Curriculum when incorporating HOTS. }\end{array}$ & 2.83 & A \\
\hline \begin{tabular}{l} 
Average mean \\
\hline
\end{tabular} & 2.99 & \\
\hline \begin{tabular}{l} 
Teachers Preparation \\
\hline
\end{tabular} & & \\
\hline
\end{tabular}

Table 2: Teacher's Preparation

(Interpretation :3.26 - 4.00 -Strongly agree (SA);2.51 - 3.25 Agree(A) ; 1.76 - 2.50Disagree(D);1.00 - 1.75 -Strongly disagree (SD).

\section{Factor of the Pupils}

Based on the interpreting values, items 1 and 4 has the highest mean of 2.60. In terms of character and focus, most of the respondents agree that they can incorporate HOTS in a range of traits and behaviours of pupils in the classroom (60\%) and can generate focus in pupils' learning when incorporating HOTS (53.3\%). Based on the responses gathered in the questionnaires on the challenges, most of the respondents find it is hard to apply HOTS in the classroom with various pupil's learning ability. Over $50 \%$ of respondents disagree with the statement in item 2 . This is supported by the response in item 3 with the mean of 2.433, which teachers find it challenging to incorporate for pupils who have not learned all the skills of reading, reasoning, writing, and reasoning. 
INTERNATIONAL JOURNAL OF ACADEMIC RESEARCH IN PROGRESSIVE EDUCATION AND DEVELOPMENT

Vol. 10, No. 2, 2021, E-ISSN: 2226-6348 @ 2021 HRMARS

\begin{tabular}{|l|l|l|}
\hline Items & Mean & Interpretation \\
\hline $\begin{array}{l}\text { 1. I can integrate HOTS into a range of } \\
\text { traits and behaviors of } \\
\text { pupils in the classroom. }\end{array}$ & 2.47 & DA \\
\hline $\begin{array}{l}\text { 2.I can incorporate HOTS with various } \\
\text { pupil's learning abilities. }\end{array}$ & 2.4667 & DA \\
\hline
\end{tabular}

\section{I can incorporate HOTS for pupils who 2.4333 DA} have not learned all the reading, writing, and reasoning skills.

\section{I can generate focus in pupils' \\ $2.60 \quad$ A}

learning when incorporating HOTS.
Average Mean
2.524
A

Table 3: Factor of Pupils

(Interpretation :3.26 - 4.00 -Strongly agree (SA);2.51 - 3.25 Agree(A) ; 1.76 - 2.50Disagree(D);1.00 - 1.75 -Strongly disagree (SD).

Open ended question from the questionnaires

\begin{tabular}{|c|c|c|}
\hline No & Themes & Participants' Respondent \\
\hline 1. & Teacher's Knowledge & $\begin{array}{l}\text { - I keep asking my colleagues if my lesson do } \\
\text { incorporate HOTS, especially when generating } \\
\text { question. } \\
\text { - I am not confident to include elements of } \\
\text { critical thinking, Logical Thinking, problem- } \\
\text { solving, and reasoning skills in an activity that I } \\
\text { give to the student } \\
\text { - I am not an English option teacher, so my } \\
\text { knowledge is relatively low }\end{array}$ \\
\hline 2 & Teacher's Preparation & $\begin{array}{l}\text { - I had to rush finishing the lesson and incorporate } \\
\text { - HOTS at the same time. } \\
\text { - Time consuming } \\
\text { Tight scheduled make HOTS activity challenging } \\
\text { to plan. }\end{array}$ \\
\hline 3. & Factor of Students & $\begin{array}{l}\text { - Some students stray from the topic and does not } \\
\text { answer the questions } \\
\text { - } \text { Attention span of pupils varied } \\
\text { - } \text { Pupils were not confident in doing HOTS activity } \\
\text { - Big number of pupils } \\
\text { - Students are struggling in reading lengthy } \\
\text { statements, especially low proficiency students. }\end{array}$ \\
\hline
\end{tabular}


INTERNATIONAL JOURNAL OF ACADEMIC RESEARCH IN PROGRESSIVE EDUCATION AND

DEVELOPMENT

Vol. 10, No. 2, 2021, E-ISSN: 2226-6348 @ 2021 HRMARS

Table 4: Thematic analysis from open-ended questions in the questionnaires

\section{Discussion}

The discussion of this research report is expanded upon to address the research study's research question.

\section{RQ 1: What are the teachers' challenges while incorporating the HOTS in teaching English classrooms?}

The first obstacle that teachers encounter when incorporating HOTS into their English classes is a lack of expertise. The participants admitted that the abilities they learned did not yet match the HOTS learning standards. Nonetheless, considering their dissatisfaction with the local government's HOTS planning and workshop, the participants achieved it. Teachers' engagement in HOTS courses has significantly impacted their familiarity with HOTS applications (Abdullah et al., 2017). In the learners' responses, they acknowledged that they lacked trust while implementing HOTS in the English classroom and relied solely on fundamental questioning.

According to research, teachers unfamiliar with the definition and vocabulary of HOTS are unable to reach the HOTS targets. Teacher design focuses solely on low to medium-level concerns rather than high-level issues (Mahamod \& Lim, 2016; Peng \& Nadaraja, 2016). In addition, they lack proper awareness of interviewing methods and the concept of Socratic queries (Seman, Yusoff \& Embong, 2017). In terms of teacher awareness of HOTS, the bulk of teachers just had a fundamental understanding of HOTS and had doubts about specific main components of HOTS. It can be inferred that teachers need intensive HOTS instruction. The most challenging task for these instructors was teaching them what they did not fully understand and transferring skills to students they did not fully master. Teachers who did not understand HOTS would lack HOTS competencies, which would hinder their teaching HOTS.

The second obstacle that teachers encounter is teacher preparation. Teachers faced challenges in meeting deadlines and delivering outcomes, controlling time, maintaining the seamless running of the teaching and learning method, content, and classroom environment. Since the respondents agree that incorporate HOTS is time-consuming, juggling both targets in a short time frame was tough. They maintained that they often had to choose between achieving HOTS targets and completing the syllabus since time was one of the most important factors that could obstruct the incorporation of HOTS in teaching.

Regarding HOTS tasks, participants must first consider the core of HOTS and then plan appropriate exercises to encourage students' mindsets through the scope of imagination and problem-solving. The findings of this study may be related to what other scholars have discovered. Most teachers need to develop their HOTS questions expertise through incorporating students' creativity, problem-solving, and analytical thinking capabilities (Setiawan et al., 2018), which takes time to design and prepare. The participants in this study, who were English instructors, found it challenging to balance their time planning HOTS assignments with their tight schedule. This is supported by Norsamsinar et al (2014), who contend that teachers bear additional work that has little connection to their teaching and learning, both institutional events, students, and day-day-to-day management tasks. 
This research also discovered that teachers faced significant difficulties because of their students' cognitive abilities, mastery of basic or prior skills, and concentration. Most teachers indicated that some students, especially those who were unable to master basic skills, need extra guidance all the way. The respondents added that some pupils do not have confidence when dealing with HOTS activity, and some even stray from it and do not answer the questions.

It was difficult for teachers to restructure lessons for all students to gain both subject awareness and HOTS. Since teachers saw HOTS and subject matter as two distinct entities, the individuality of each pupil made it difficult for teachers to concentrate on both subject matter and HOTS. A considerable number of pupils in one class that is express in this study should not be ignored. Research by Sulaiman T et al. (2017), The number of students in a class prevents the instructor from being as successful as she/he would like to be. In a well-balanced distribution, the appropriate class size must be determined.

\section{Conclusion and Recommendation}

This study explored the difficulties that teachers encounter in incorporating the ability of Higher Order Thinking into teaching. This challenge is part of what teachers need to conquer to acquire, as outlined by the MOE, the attributes of 21st-century teachers (Hayati Nor \& Kamarolzaman,2015). Each teacher must be competent, trained in his or her profession as a mediator and facilitator of students to equip students with the skills they need for future success. Every instructor must also be capable of working both as a mediator and a receiver of the future, so he or she should help students build up their present abilities, so they can have more excellent long-term benefits. Teachers of English should be trained on pedagogical methods for teaching English and in tactics and on Higher-Order Skills (HOTS). Efforts can also be made to minimize class size. A teacher's efficacy is significantly reduced when there are so many students in a class. Logical and rational class size must be determined. If Malaysia sincerely wishes to see the HOTS concept realized, the program must be monitored and improved on a severe and constant basis

\section{Contribution}

As a result, this research has been able to identify some of the challenges that is faced by the teacher when incorporate HOTS in English classroom. Therefore, this research contribute to raise awareness among English teachers to be well educated and equipped with information about HOTS where they will confront a variety of challenges and possibilities that will demand them to improve to address those challenges.

Lastly, this research also contribute to help the policymakers or the government to provide other alternatives to help the teachers that faced the challenges as been discovered in this research.

\section{References}

Abdullah, A. H., Mokhtar, M., Abd Halim, N. D., Ali, D. F., Tahir, M. L., \& Abdul Kohar, U. H. (2017). Mathematics Teachers' Level of Knowledge and Practice on the Implementation of HigherOrder Thinking Skills (HOTS). Eurasia Journal of Mathematics, Science and Technology Education, 13(1), 3-17.

Anderson, L. W., and Krathwohl, D. (eds.) (2001). A Taxonomy for Learning, Teaching and Assessing a Revision of Bloom's Educational Objectives. New York: Longman. 
INTERNATIONAL JOURNAL OF ACADEMIC RESEARCH IN PROGRESSIVE EDUCATION AND

DEVELOPMENT

Vol. 10, No. 2, 2021, E-ISSN: 2226-6348 @ 2021 HRMARS

Asún, R. A., Rdz-Navarro, K., \& Alvarado, J. M. (2016). Developing Multidimensional Likert Scales Using Item Factor Analysis: The Case of Four-point Items. Sociological Methods \& Research,45(1), 109-133.

Creswell, J. W., \& Guetterman, T. C. (2019). Educational Research: Planning, Conducting, and Evaluating Quantitative and Qualitative Research,6.

Fern, C. C. S., and Umi Kalsum, M. S. (2015). The emphasis of Higher Order Thinking (HOT) in the curriculum and the implementation in reality. In Knowledge, Service, Tourism \& Hospitality: Proceedings of the Annual International Conference on Management and Technology in Knowledge, Service, Tourism \& Hospitality.

Ganapathy, M., Singh, M. K. M., Kaur, S., \& Kit, L. W. (2017). Promoting Higher Order Thinking Skills via Teaching Practices. 3L: The Southeast Asian Journal of English Language Studies ,23(1), 75-85

Latief, J. A., Pabbajah, M., \& Karim, S. A. (2016). The implementation of higher order thinking Higher order thinking skills among English teachers across generation in EFL classroom skills at Universitas Teknologi Yogyakarta in Indonesia: Opportunities and challenges. Proceeding of International Conference on Education and Higher Order Thinking Skills (ICE-HOTS),1,80-90.

Preece, A. S., and Adila, J. (2014). Philosophical Inquiry in the Malaysian Educational SystemReality or Fantasy? Analytic Teaching and Philosophical Praxis, 35 (1).

Rajendran, N. (2001). The Teaching of Higher-Order Thinking Skills in Malaysia Journal of Southeast Asian Education; 2(1),42-65.

Seman, S. C., Yusoff, W. M. W., \& Embong, R. (2017). Teachers challenges in teaching and learning for higher order thinking skills (HOTS) in primary school. International Journal of Asian Social Science, 7(7),534-545.

Setiawan, A., Anggani, D., \& Bharati, L. (2018). Developing HOT Project-Based-Speaking Assessment to Stimulate the Students' Critical Thinking and Creativity. English Education Journal, 8(3),301-307.

Sulaiman, T., Muniyan, V., Madhvan, D., Ehsan, S. D., Persekutuan, W., \& Lumpur, K. (2017). International Research Journal of Education and Sciences (IRJES),1(1).

Yeung, S. S. (2015). Conception of Teaching Higher Order Thinking: Perspectives of Chinese Teachers in Hong Kong. The Curriculum Journal, 26 (4),553-578. 